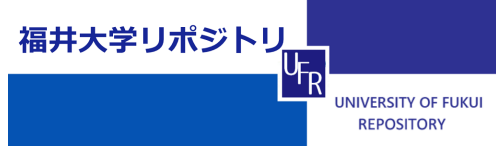

Meni ngeal pl asma cel I granul oma wi th rel apsi ng pol ychondri i is

\begin{tabular}{|c|c|}
\hline 著者 & $\begin{array}{l}\text { SATO Kazuf umi, KUBOTA Toshi hi ko, K TAl Ryuhei, } \\
\text { M YAMORI I sami }\end{array}$ \\
\hline $\begin{array}{l}\text { journal or } \\
\text { publ i cat } i \text { on } \mathrm{title}\end{array}$ & Jour nal of neur osurger y \\
\hline vol une & 104 \\
\hline number & 1 \\
\hline page $r$ ange & $143-146$ \\
\hline year & 2006-01 \\
\hline URL & ht t p: //hdl . handl e. net /10098/1831 \\
\hline
\end{tabular}


J Neurosurg 104:143-146, 2006

\title{
Meningeal plasma cell granuloma with relapsing polychondritis
}

\author{
Case report
}

\author{
Kazufumi Sato, M.D., Toshiniko Kubota, M.D., Ryuhei Kitai, M.D., \\ AND ISAMU MIYAMORI, M.D.
}

Division of Neurosurgery, Department of Sensory and Locomotor Medicine, and Third Department of Internal Medicine, Faculty of Medical Sciences,University of Fukui, Japan

\begin{abstract}
Relapsing polychondritis (RP) is a rare systemic disease characterized by recurrent inflammation of the cartilaginous structures and connective tissue. Central nervous system lesions in association with RP have occasionally been reported, but intracranial mass lesions have not been described. The authors report the first such case, in which a 51year-old man presented with parasagittal meningeal plasma cell granuloma with RP. The mass was subtotally resected and adjuvant radiotherapy was administered. The patient did not experience any recurrence of the lesion during an 8-year follow-up period. In this case, the exact diagnosis of RP was made based on symptoms of respiratory tract chondritis, which was successfully treated by the placement of tracheobronchial stents.
\end{abstract}

\section{KEY WORDS - relapsing polychondritis - meningeal plasma cell granuloma • central nervous system lesion • intracranial mass lesion}

$\mathrm{R}$ ELAPSING polychondritis is an uncommon, chronic and progressive inflammatory disease with multisystem involvement, which is presumed to have an autoimmune cause..$^{16,20,21,26}$ Relapsing polychondritis affects the cartilage in multiple organs, such as the nose, ear, trachea, bronchi, and joints. The diagnosis of RP is based on the presence of clinical criteria, including bilateral auricular chondritis, nonerosive seronegative inflammatory polyarthritis, nasal chondritis, respiratory tract chondritis, and audiovestibular damage. ${ }^{20}$ Nevertheless, the initial clinical symptoms of RP are not always typical, and the early diagnosis of this disease is often difficult. ${ }^{22,26}$

Central nervous system involvement is a rare condition in $\mathrm{RP}$, and aseptic meningitis, ${ }^{1,3,11,14}$ cerebral aneurysm,,${ }^{5,24}$ and vasculitis, ${ }^{6,19,23,25,27}$ have been reported. To our knowledge, however, no intracranial mass lesion has previously been described as a CNS complication. We present a case in which a meningeal PCG was the initial manifestation of RP.

\section{Case Report}

Presentation and Examination. This 51-year-old man was admitted to our hospital in July 1996 for headache and nasal

\footnotetext{
Abbreviations used in this paper: $\mathrm{CNS}=$ central nervous system; $\mathrm{MR}=$ magnetic resonance; $\mathrm{PCG}=$ plasma cell granuloma; $\mathrm{RP}=$ relapsing polychondritis.
}

congestion of 3 weeks' duration. On admission, no abnormalities were detected on neurological examination. Routine blood tests demonstrated leukocytosis $(27,800$ cells/ $\left.\mathrm{mm}^{3}\right)$ and an elevated level of C-reactive protein $(>13.8$ $\mathrm{mg} / \mathrm{l})$. There was no sign of rheumatoid factor or antinuclear antibodies, and the serum immunoglobulin level was normal. The patient did not present with lymphadenopathy, and a bone marrow biopsy specimen did not demonstrate any abnormality. Immediately after admission, he began to complain of intermittent bilateral finger and ankle arthralgia, which was improved by low-dose steroid therapy (prednisone $0.3 \mathrm{mg} / \mathrm{day}$ ).

Magnetic resonance imaging demonstrated an irregular left parasagittal mass focally invading the skull. The mass displayed a low signal intensity on $\mathrm{T}_{1}$-weighted images and was markedly enhanced (Fig. 1 upper). The lesion exhibited a high signal intensity on $\mathrm{T}_{2}$-weighted imaging (Fig. 1 lower left). Magnetic resonance imaging of the nasal cavity revealed a mass lesion of the nasal septum (Fig. 1 lower right).

Operation and Postoperative Course. A frontal craniotomy was performed, and a firm meningeal mass mimicking a meningioma was demonstrated. The mass focally invaded the skull and was adherent to the cerebrum. The lesion was subtotally excised, and the postoperative course was uneventful.

Pathological Findings. Histologically, the tumor was com- 
K. Sato, et al.

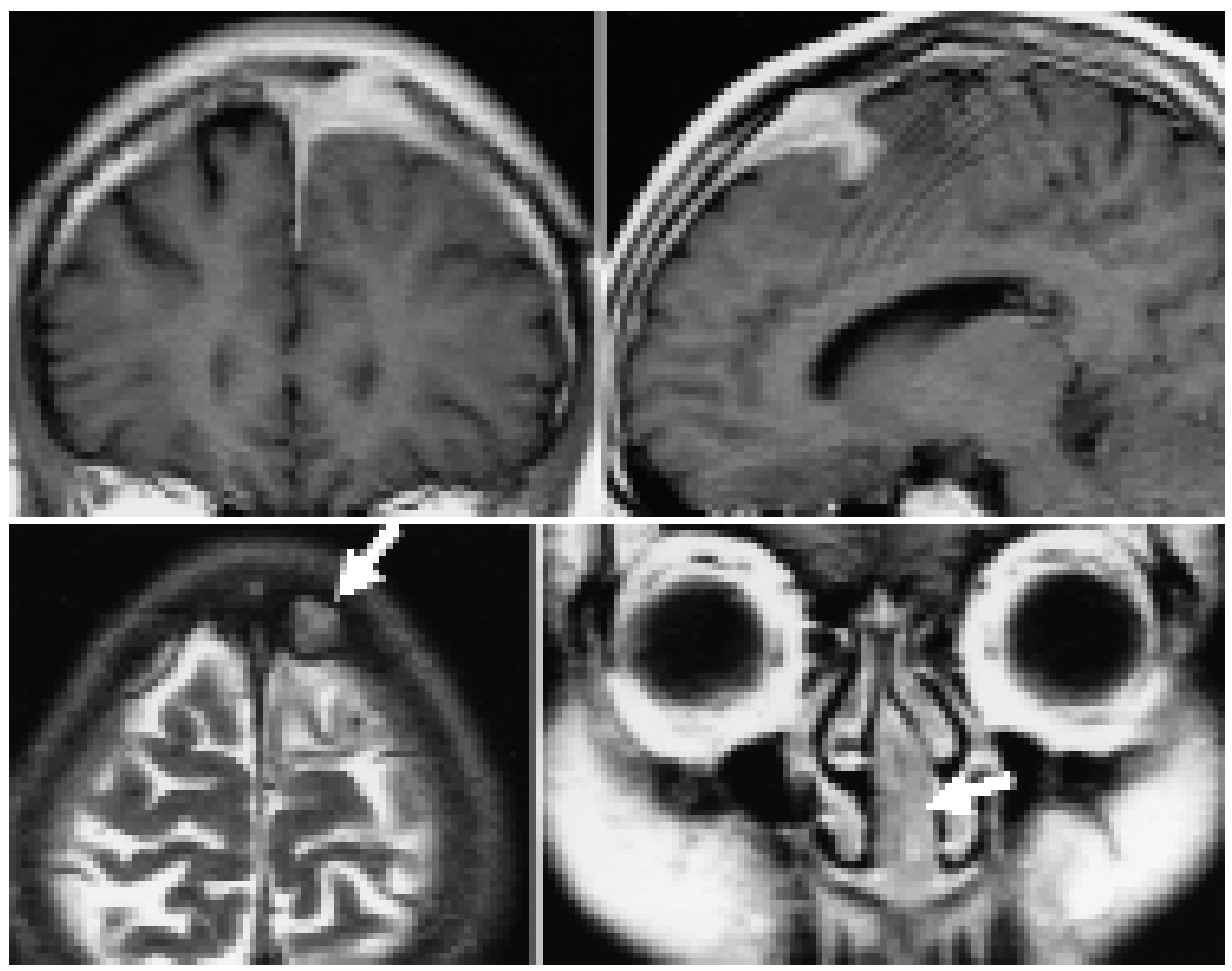

FIG. 1. Upper: Coronal (left) and sagittal (right) contrast-enhanced MR images revealing an irregular parasagittal enhancing mass, which has focally invaded the skull. Lower: Axial $\mathrm{T}_{2}$-weighted MR image demonstrating a mass with a high signal intensity (left, arrow) and a contrast-enhanced coronal MR image of the nasal cavity depicting a diffuse thickening mass of the nasal septum (right, arrow).

posed of a dense inflammatory infiltrate consisting predominantly of mature plasma cells associated with occasional lymphocytes and histiocytes (Fig. 2). Russell bodies were frequently observed. There were no clusters of meningothelial cells or any emperipolesis. Immunohistochemically, the plasma cells were positive for both kappa and lambda light

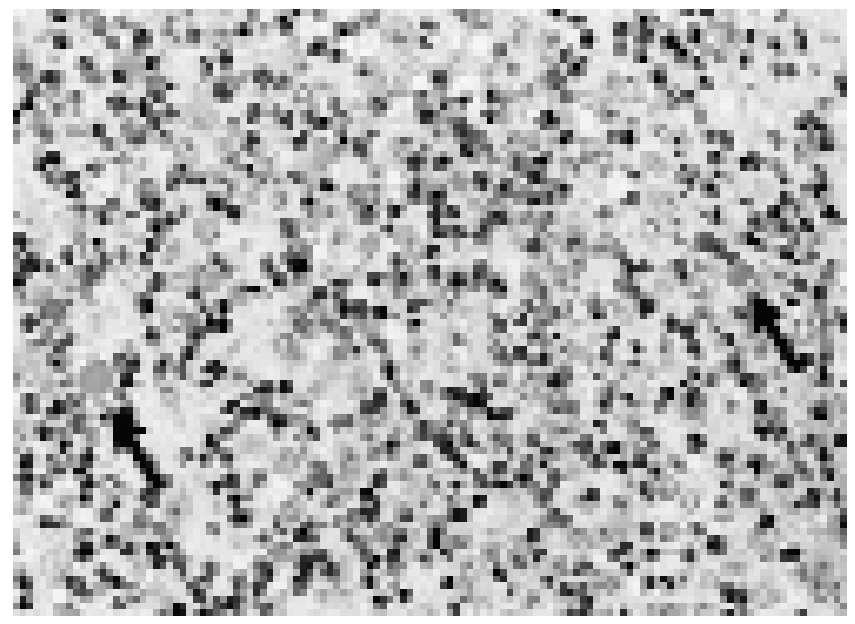

FIG. 2. Photomicrograph of a specimen of the parasagittal mass showing proliferation of numerous inflammatory cells predominantly composed of mature plasma cells. Russell bodies are also seen (arrows). H \& E, original magnification $\times 200$. chains. All these histopathological findings were consistent with meningeal PCG. Nevertheless, a biopsy specimen of the nasal septum was found to be composed of fibrocollagenous tissue with inflammatory cell proliferation, including neutrophils, lymphocytes, histiocytes, and occasional

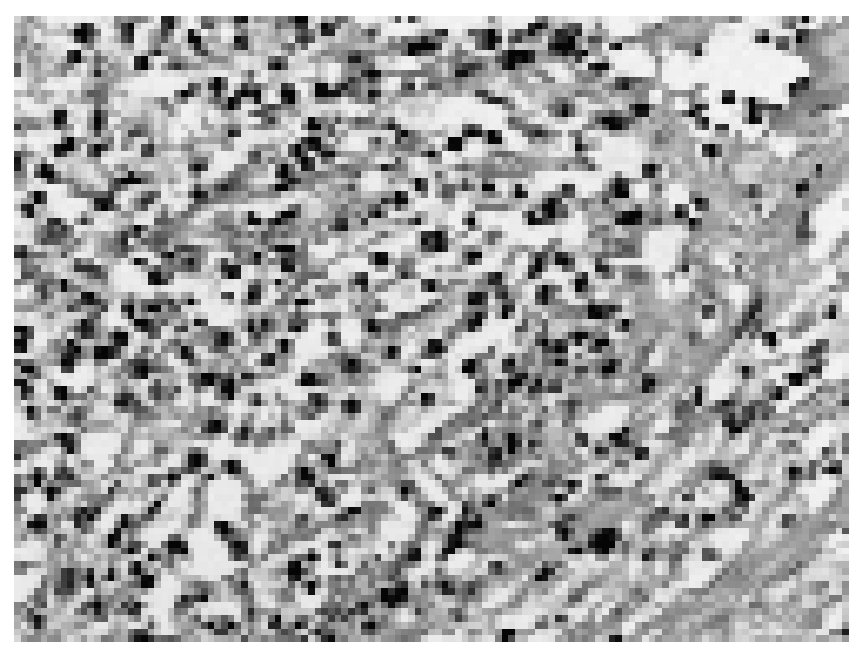

FIG. 3. Photomicrograph of a specimen of the nasal lesion showing inflammatory cells in the fibrocollagenous tissue, including neutrophils, lymphocytes, histiocytes, and plasma cells. The final diagnosis was severe inflammation of the nasal septum (chondritis caused by RP). $\mathrm{H} \& \mathrm{E}$, original magnification $\times 200$. 


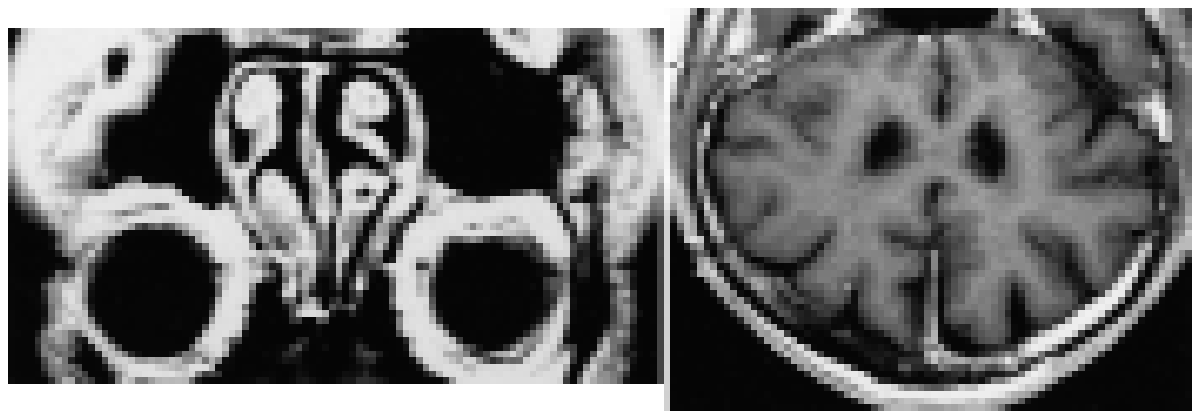

FIG. 4. Contrast-enhanced coronal MR images obtained in 2004 demonstrating no sign of recurrence of the nasal (left) and intracranial (right) lesions.

plasma cells (Fig. 3). At that time, the provisional diagnosis was inflammatory granuloma with a composition differing from that of the intracranial lesion.

Adjuvant Therapy. The residual intracranial and nasal lesions were subjected to 40 and 30 Gy of radiation, respectively.

Posttreatment Course. The patient was discharged in October 1996 without any neurological deficit, and he continued to take oral low-dose steroid medications at home.

Additional Presentations and Treatments. In August 2000, the patient experienced a sudden onset of respiratory distress. Based on a diagnosis of stenosis of the tracheobronchial tree, the patient was treated with high-dose steroid medications and tracheostomy, resulting in a clinically complete response. Because of the moderate elevation of serum anti-collagen II antibody (the optical density at 450 was 0.706 and the dilution was 1:100; the normal control range is $0.065-0.14$ ), a diagnosis of RP was made. This time we concluded that the previous lesion of the nasal septum had been severe chondritis associated with RP. After a full recovery from this first respiratory episode, the patient remained stable for 3 years. In May 2003, he again experienced a sudden onset of severe dyspnea, and a diagnosis of severe tracheobronchomalasia due to RP was made. Endotracheal and endobronchial stents were implanted, resulting in a marked improvement in the patient's respiratory distress. In October 2004, the patient's status continued to be progression free of intracranial and nasal lesions for 8 years (Fig. 4).

\section{Discussion}

Relapsing polychondritis is a chronic inflammatory disease associated with an autoimmune disorder of the cartilage, eyes, and labyrinth. ${ }^{16,20,26}$ The diagnosis of this disease is usually based on the clinical criteria proposed by McAdam and colleagues..$^{20}$ Although the cause of RP remains unknown, an immunological reaction to type II collagen has been implicated. , $, 8,16,26$ In 20 to $30 \%$ of patients, the level of serum antibody against collagen II is elevated. ${ }^{8,26}$

It has been noted that an early diagnosis of RP is often difficult. 22,26 Trentham and $\mathrm{Le}^{26}$ reported that the average time delay from onset to diagnosis was 2.9 years. In our case, because the initial symptoms were not typical of RP, a precise diagnosis was not made until the characteristic syndromes of severe airway stenosis appeared. Moderately ele- vated levels of serum collagen II antibody provided an additional key to the diagnosis of RP. It was retrospectively proven that the initial presentation of the nasal lesion (chondritis of the nasal septum) and polyarthritis were also symptoms of RP. . $^{1,20,26}$

The association of an intracranial lesion with RP has occasionally been described. . $3,5,6,11,14,19,23-25,27$ To our knowledge, however, this is the first reported occurrence of an intracranial mass lesion, a PCG, in a patient with RP. Although the relationship between RP and meningeal PCG is uncertain, an autoimmune origin might be considered in cases of aseptic meningitis associated with RP.,11

Meningeal PCG of the CNS is a rare inflammatory lesion that is histologically characterized by tumorlike proliferation of polyclonal plasma cells against a background of fibrous stroma., $2,7,7,10,12,15,17,18$ Meningeal PCG should be differentiated from plasmacytoma, lymphoplasmacyte-rich meningioma, and meningeal sinus histiocytosis (RosaiDorfman disease). The polyclonal nature of the plasma cell infiltration ruled out plasmacytoma. The absence of meningothelial cell nests and the lack of emperipolesis in our case were not compatible with lymphoplasmacyte-rich meningioma and meningeal sinus histiocytosis, respectively..$^{13}$

Resection is the first choice of treatment for an intracranial PCG, and postoperative radiation therapy is a useful adjuvant, especially for an incompletely excised lesion.,2,412,17 In the present case, the unusual skull invasion was suggestive of an aggressive nature, which also supports the use of radiotherapy. The patient's intracranial lesion has not recurred during 8 years of follow-up review.

The prognosis of RP is linked to laryngeal, tracheal, and cardiovascular involvement, and the most dangerous symptom is acute airway collapse, ${ }^{22}$ as was observed in our case. A greater recognition of RP would lead to an earlier diagnosis and improve the patient's outcome. ${ }^{21,26}$ Furthermore, despite its rarity, CNS complications including an intracranial mass lesion must be considered in a patient with RP.

\section{References}

1. Berg AM, Kasznica J, Hopkins P, Simms RW: Relapsing polychondritis and aseptic meningitis. J Rheumatol 23:567-569, 1996

2. Brandsma D, Jansen GH, Spliet W, Van Nielen K, Taphoorn MJ: The diagnostic difficulties of meningeal and intracerebral plasma cell granulomas - presentation of three cases. J Neurol 250: 1302-1306, 2003 
3. Brod S, Booss J: Idiopathic CSF pleocytosis in relapsing polychondritis. Neurology 38:322-323, 1988

4. Cannella DM, Prezyna AP, Kapp JP: Primary intracranial plasmacell granuloma. Case report. J Neurosurg 69:785-788, 1988

5. Coumbaras M, Boulin A, Piette AM, Graveleau P, Bletry O, Pierot $\mathrm{L}$ : Intracranial aneurysm associated with relapsing polychondritis. Neuroradiology 43:565-566, 2001

6. Dreher A, Aigner J, Fuchshuber S, Kastenbauer E: Relapsing polychondritis: a course over 20 years with cerebral involvement. Arch Otolaryngol Head Neck Surg 126: 1495-1498, 2000

7. Figarella-Branger D, Gambarelli D, Perez-Castillo M, Garbe L, Grisoli F: Primary intracerebral plasma cell granuloma: a light, immunocytochemical, and ultrastructural study of one case. Neurosurgery 27:142-147, 1990

8. Foidart JM, Abe S, Martin GR, Zizic TM, Barnett EV, Lawley TJ, et al: Antibodies to type II collagen in relapsing polychondritis. $\mathbf{N}$ Engl J Med 299:1203-1207, 1978

9. Gangemi M, Maiuri F, Giamundo A, Donati P, De Chiara A: Intracranial plasma cell granuloma. Neurosurgery 24:591-595, 1989

10. Gochman GA, Duffy K, Crandall PH, Vinters HV: Plasma cell granuloma of the brain. Surg Neurol 33:347-352, 1990

11. Hanslik T, Wechsler B, Piette JC, Vidailhet M, Robin PM, Godeau P: Central nervous system involvement in relapsing polychondritis. Clin Exp Rheumatol 12:539-541, 1994

12. Hirohata M, Sasaguri Y, Sugita Y, Tokutomi T, Kobayashi S, Morimatsu M, et al: Intracranial plasma-cell granuloma: a case report. Noshuyo Byori 13:133-138, 1996

13. Kitai R, Sato K, Kubota T, Kabuto M, Kawano H, Kobayashi H, et al: Meningeal sinus histiocytosis mimicking lymphoplasmacyte-rich meningioma. Case report. J Neurosurg 84:1051-1054, 1996

14. Kothare SV, Chu CC, VanLandingham K, Richards KC, Hosford DA, Radtke RA: Migratory leptomeningeal inflammation with relapsing polychondritis. Neurology 51:614-617, 1998

15. Le Marc'hadour F, Fransen P, Labat-Moleur F, Passagia JG, Pasquier B: Intracranial plasma cell granuloma: a report of four cases. Surg Neurol 42:481-488, 1994

16. Letko E, Zafirakis P, Baltatzis S, Voudouri A, Livir-Rallatos C, Foster CS: Relapsing polychondritis: a clinical review. Semin Arthritis Rheum 31:384-395, 2002
17. Maeda Y, Tani E, Nakano M, Matsumoto T: Plasma-cell granuloma of the fourth ventricle. Case report. J Neurosurg 60: 1291-1296, 1984

18. Makino K, Murakami M, Kitano I, Ushio Y: Primary intracranial plasma-cell granuloma: a case report and review of the literature. Surg Neurol 43:374-378, 1995

19. Massry GG, Chung SM, Selhorst JB: Optic neuropathy, headache, and diplopia with MRI suggestive of cerebral arteritis in relapsing polychondritis. J Neuroophthalmol 15:171-175, 1995

20. McAdam LP, O'Hanlan MA, Bluestone R, Pearson CM: Relapsing polychondritis: prospective study of 23 patients and a review of the literature. Medicine (Baltimore) 55:193-215, 1976

21. Michet CJ Jr, McKenna CH, Luthra HS, O'Fallon WM: Relapsing polychondritis. Survival and predictive role of early disease manifestations. Ann Intern Med 104:74-78, 1986

22. Sarodia BD, Dasgupta A, Mehta AC: Management of airway manifestations of relapsing polychondritis: case reports and review of literature. Chest 116:1669-1675, 1999

23. Stewart SS, Ashizawa T, Dudley AW Jr, Goldberg JW, Lidsky MD: Cerebral vasculitis in relapsing polychondritis. Neurology 38:150-152, 1988

24. Strobel ES, Lang B, Schumacher M, Peter HH: Cerebral aneurysm in relapsing polychondritis. J Rheumatol 19:1482-1483, 1992

25. Sundaram MB, Rajput AH: Nervous system complications of relapsing polychondritis. Neurology 33:513-515, 1983

26. Trentham DE, Le CH: Relapsing polychondritis. Ann Intern Med 129:114-122, 1998

27. Willis J, Atack EA, Kraag G: Relapsing polychondritis with multifocal neurological abnormalities. Can J Neurol Sci 11: 402-404, 1984

Manuscript received March 1, 2005.

Accepted in final form May 10, 2005.

Address reprint requests to: Kazufumi Sato, M.D., Division of Neurosurgery, Department of Sensory and Locomotor Medicine, Faculty of Medical Sciences, University of Fukui, 23 Shimoaizuki, Matsuoka-cho, Yoshida-gun, Fukui 910-1193, Japan. email: ksato@ fmsrsa.fukui-med.ac.jp. 